\title{
Hepatitis in Selective IgA Deficiency
}

\author{
JOCHANAN BENBASSAT, LEAH KEREN, AVINOAM ZLOTNIC
}

suspected abnormalities in the serum protein pattern on cellulose acetate membrane electrophoresis. The sera of about 750 patients with suspected abnormalities on immunoelectrophoresis were further assayed for serum immunoglobulin

\section{Summary}

Hepatitis occurred in five out of 12 patients with selective IgA deficiency who had been detected by immunelectrophoretic screening of 2,600 individuals. This apparent increased susceptibility to hepatitis has not been reported before, and it may be due to the defect in their local and humoral immune mechanisms.

\section{Introduction}

The main immunoglobulin component of the body secretions is IgA (Tomasi, 1968). This type of immunoglobulin is believed to be the main factor in the local immune defence (Ammann and Hong, 1971). IgA deficiency occurs in patients with primary or acquired hypogammaglobulinaemias as a part of the generalized deficiency in immunoglobulins. More commonly, it may occur as a manifestation of an isolated, probably hereditary, defect in antibody production in patients with an apparently normal serum gammaglobulin pattern on electrophoresis (Hobbs, 1968). Most patients with selective IgA deficiency are detected during evaluation for recurrent respiratory infections, "autoimmune" disorders, or malabsorption (Ammann and Hong, 1971). The purpose of this report is to present 12 additional cases of IgA deficiency, and to draw attention to the association of hepatitis with this type of dysgammaglobulinaemia.

\section{Subjects and Methods}

Serum examinations by immunoelectrophoresis were performed over a period of three years (1970-2) in some 2,600 patients. The choice of whether immunoelectrophoresis should be carried out was biased in favour of patients with (1) symptoms or signs suggestive of an autoimmune disorder or malabsorption; (2) recurrent infections; (3) liver disease; and (4)

Department of Medicine $A$ and Research Laboratory for Autoimmune Diseases, Hadassah University Hospital and Medical School, Jerusalem, Israel

JOCHANAN BENBASSAT, M.D., Senior Lecturer in Medicine

LEAH KEREN, Research Assistant

LEAH KEREN, Research Assistant Head of Research Laboratory for Autoimmune Diseases levels. Twelve patients with selective IgA deficiency were thus detected. One of the cases was found among the investigated relatives of patients with this disorder and another one was detected among the normal controls. Immunoelectrophoresis was carried out with the microapparatus of Scheidegger (1955) using barbital buffer ( $\mathrm{pH} \mathrm{8.2)}$. Antiwhole human serum (Hyland Laboratories, California, U.S.A.), was used. Serum immunoglobulin levels were determined by radial immunodiffusion (Mancini et al., 1965) using goat anti-IgA, anti-IgM, and anti-IgG sera (Meloy Laboratories, Virginia, U.S.A.). The normal values (means + S.D.) in this laboratory as determined in 400 normal adults are: IgG, $1157 \pm 378$; IgA, $224 \pm 96$; and IgM, $134 \pm 52 \mathrm{mg} / 100 \mathrm{ml}$ serum. Cases of selective IgA deficiency associated with multiple myeloma, chronic lymphatic leukaemia, or macroglobulinaemia were not included in this series.

\section{Results}

Selective IgA deficiency was detected in two healthy subjects and in 10 symptomatic patients. The immunoglobulin levels and associated diseases of these patients are given in the table.

Five patients had hepatitis. In three of them the course of the disease suggested uncomplicated viral hepatitis. In the founth the disturbance of the liver function disappeared only a year after the onset of the disease; a liver biopsy specimen taken seven months after onset was interpreted as compatible with chronic persistent viral hepatitis. The fifth patient had had acute hepatitis at the age of 8 years. During the next six years she remained jaundiced, with progressive splenomegaly and persistent disturbance in the liver function tests. A liver needle biopsy specimen taken two years after the onset of her disease was interpreted as compatible with chronic active hepatitis. She has been treated for the past six years with prednisone $30-40 \mathrm{mg}$ daily, and for the past three years with azathioprine $50-100 \mathrm{mg}$ daily.

\section{Discussion}

The prevalence of selective IgA deficiency in this series was about $1: 230$. This value is higher than that observed by Hobbs (1968) and Bachman (1968), who reported a prevalence of $1: 500$ to $1: 700$ among their patients. The possibility that

Serum Immunoglobulins $(\mathrm{mg} / 100 \mathrm{ml})$ in Patients under Study

\begin{tabular}{|c|c|c|c|c|c|c|}
\hline Case No. & Sex & Age & IgG & $\operatorname{Ig} A$ & IgM & Clinical Details \\
\hline $\begin{array}{l}1 \\
2 \\
3 \\
4 \\
5\end{array}$ & $\begin{array}{l}\text { M. } \\
\text { F. } \\
\text { M. } \\
\text { F. } \\
\text { F. }\end{array}$ & $\begin{array}{l}14 \\
30 \\
28 \\
21 \\
13\end{array}$ & $\begin{array}{c}2.350 \\
500 \\
1,625 \\
1,600 \\
4,300\end{array}$ & $\begin{array}{c}0 \\
0 \\
0 \\
\text { Traces } \\
10\end{array}$ & $\begin{array}{r}350 \\
85 \\
110 \\
250 \\
250\end{array}$ & $\begin{array}{l}\text { Infectious hepatitis } \\
\text { Recurrent sinopulmonary infections. Infectious hepatitis at age } 14 \\
\text { Recurrent sinopulmonary infections. Infectious hepatitis } \\
\text { Chronic persistent hepatitis } \\
\text { Chronic active hepatitis-diabetes-steroid induced. Recurrent pulmonary in- } \\
\text { fections }\end{array}$ \\
\hline $\begin{array}{r}6 \\
7 \\
8 \\
9 \\
10 \\
11 \\
12\end{array}$ & $\begin{array}{l}\text { M. } \\
\text { M. } \\
\text { M. } \\
\text { F. } \\
\text { M. } \\
\text { M. } \\
\text { M. }\end{array}$ & $\begin{array}{r}7 \\
74 \\
72 \\
13 \\
40 \\
45 \\
50\end{array}$ & $\begin{array}{r}1,750 \\
2,900 \\
1,400 \\
950 \\
4,000 \\
1,950 \\
900\end{array}$ & $\begin{array}{l}0 \\
0 \\
0 \\
\text { Traces } \\
\text { Traces } \\
\text { Traces } \\
\quad 27\end{array}$ & $\begin{array}{r}125 \\
105 \\
60 \\
225 \\
100 \\
48 \\
105\end{array}$ & $\begin{array}{l}\text { Spastic bronchitis } \\
\text { Chronic bronchitis. Diabetes mellitus } \\
\text { Rheumatoid arthritis } \\
\text { Autoimmunc haemolytic anaemia } \\
\text { Recurrent infections } \\
\text { Asymptomatic } \\
\text { Aysmptomatic }\end{array}$ \\
\hline
\end{tabular}


selective IgA deficiency is more common among Jews than among other ethnic groups cannot be ruled out. It seems more likely, however, that the higher prevalence of selective IgA deficiency in the present series was related to the criteria for selection of patients to be examined.

Selective IgA deficiency has been detected mainly among patients with recurrent infections, "autoimmune" disorders, or malabsorption, but also among asymptomatic individuals (Bachman, 1968; Claman et al., 1966; Johansson et al., 1968; Cassidy et al., 1968). The nature of the associated diseases in our patients with selective IgA deficiency was in general similar to that reported in the literature, but for the high incidence of hepatitis. At the time of diagnosis two patients had acute hepatitis, one had a documented history of this disease, one had chronic persistent hepatitis, and one had chronic active hepatitis.

IgA is believed to play an important part in protecting the gastrointestinal tract. Symptoms referrable to the gut, mainly malabsorption with steatorrhoea, have been observed in patients with selective IgA deficiency (Hobbs, 1968; Crabbé and Heremans, 1967; Ammann and Hong, 1971). IgA-producing plasmacytes are dominant among the lymphoid cells of the lamina propria (Crabbé and Heremans, 1967), and evidence has been presented that IgA antibodies have viral neutralizing activity (Rossen et al., 1965). Specific secretory IgA antibody to the hepatitis-associated antigen has indeed been detected in the mucosal surface by Ogra (1973). It seems likely, therefore, that a defect in the normal protective action of $\operatorname{IgA}$ in the alimentary tract, combined with a mild defect in humoral immunity, could result in a higher tendency to infections by viruses, the portal of entry of which is the gut.

We are not aware of any previous reports of a higher susceptibility of patients with selective IgA deficiency to viral hepatitis. "Lupoid" hepatitis, however, has been reported so far in five patients with selective IgA deficiency (Ammann and Hong, 1971), and one of our patients had chronic aggressive hepatitis. It is conceivable that the "immunological imbalance," postulated by Hobbs (1968) in patients with selective IgA deficiency, together with their increased susceptibility to viral hepatitis, could lead to the development of chronic aggressive hepatitis in some cases.

This study was supported by grants from the Joint Research Fund of the Hebrew University and Hadassah University Hospital and Medical Sahool and the Israel Cancer Association.

We wish to thank Professor $M$. Eliakim for his valuable comments.

\section{References}

Ammann, A. J., and Hong, R. (1971). Medicine, 50, 223. Investigation, 17,316

Investigation, 17, 316 .
sidy, J. T., Burt, A., Petty, R., and Sullivan, D. (1968). New England Fournal of Medicine, 280, 275.

Claman, H. N., Hartley, T. F., and Merrill, D. (1966). Fournal of Allergy, 38,215 .

Crabbé, P. A., and Heremans, J. E. (1967). American fournal of Medicine, 42, 319.

Hobbs, J. R. (1968). Lancet, 1, 110.

Johansson, S. G. O., Hogman, C. F., and Killander, J. (1968). Acta Pathologica et Microbiologica Scandinavica, 74, 519.

Mancini, G., Carbonara, A. O., and Heremans, J. F. (1965). Immunochemistry, 2, 235.

Ogra, P. L. (1973). Fournal of Immunology, 110, 1197.

Rossen, R. D., Butler, W. T., Cate, T. R., Szwed, C. F., and Couch, R. B. (1965). Proceedings of the Society for Experimental Biology and Medicine, (1965). Proceedings of the Society for Experimental Biology and Medicine,

Scheidegger, J. J. (1955). International Archives of Allergy and Applied Immunology, 7, 103.

Tomasi, T. B. (1968). New England Fournal of Medicine, 279, 1327.

\title{
Therapeutic Non-equivalence of Digoxin Tablets in the United Kingdom: Correlation with Tablet Dissolution Rate
}

\author{
T. R. D. SHAW, K. RAYMOND， M. R. HOWARD, JOHN HAMER
}

British Medical fournal, 1973, 4, 763-766

\section{Introduction}

\section{Summary}

Seven types of digoxin $0.25 \mathrm{mg}$ tablet in common use in the United Kingdom were administered to a total of 38 patients. Significant differences were found in the mean plasma digoxin levels and in the control of atrial fibrillation achieved with these brands. There was a close correlation between the dissolution rate of the tablets and the plasma digoxin levels. Measurement of in-vitro dissolution rate appears to be a valid method of ensuring that different tablets of digoxin are of equal efficacy. However, in some patients absorption of the drug is markedly sensitive to changes in dissolution rate and new pharmacopoeal standards should not be defined until very rapidly-dissolving formulations have been studied.

\footnotetext{
Department of Cardiology, St. Bartholomew's Hospital, London EC1A 7BE

T. R. D. SHAW, M.R.C.P., Registrar

JOHN HAMER, F.R.C.P., Consultant Cardiologist

Department of Pharmaceutics, School of Pharmacy, University of London, London W.C.1

K. RAYMOND, M.PHARM., Lecturer
}

It has become apparent that tablets of digoxin may contain the correct dose but provide only a portion of this dose for absorption by the patient. Reports from several countries have shown wide variation in absorption between different brands of tablets and even between different batches of the same brand (Lindenbaum et al., 1971; Manninen et al., 1971; Bertler et al., 1972; Shaw et al., 1972). These differences are not detected by the test for disintegration rate given in the British and U.S. pharmacopoeias (Shaw et al., 1972; Wagner et al., 1973).

We have administered to patients seven different types of digoxin tablet used in the United Kingdom and have recorded the plasma digoxin levels and clinical response obtained with each type. The digoxin level and response have been compared with the dissolution rate of the tablets to assess the validity of measurement of dissolution rate as an in-vitro test for quality control of digoxin tablet manufacture.

\section{Patients and Methods}

Of the two groups of 20 patients studied 19 of each group completed the period of study (table I). 